\title{
THE SOCIAL REFORMS OF SAN MARTIN
}

\section{$A^{s}$}

A PART OF THE CENTENNIAL celebration of the death of José de San Martín, the year 1950 was designated by the Congress of Argentina as the "Year of San Martín." Article 2 of Law 13,661 reads as follows: "From the first day of January until the thirty-first of December of the year 1950, all official documents of national, provincial and municipal authorities; the titles and diplomas granted by institutions of learning of all ranks and jurisdictions, be they of the State or incorporated; diplomatic dispatches and the notations and colophons of books, periodicals, dailies, reviews and every other class of publications whether they be official or private, national or foreign, shall be preceded by the denomination of 'Year of the Liberator General San Martín' to indicate the year 1950."1

José Francisco de San Martín is best known as the military genius on whose successes was founded the political independence of Argentina, Chile and Peru. In writing the account of his life, biographers have used such titles as "Captain of the Andes" and "Saint of the Sword." Born of Spanish parents on the Argentinian frontier at Yapeyu, February 25, 1778, he accompanied them to Spain at the age of seven and was educated for a military career. Joining the Spanish army, he fought in Africa and defended the mother country against Republican France, England, Portugal and Napoleon Bonaparte.

In 1808 , at the age of thirty, San Martín was promoted to the rank of colonel. Three years later he gave up his position in the Spanish army to return to Argentina to help win freedom for the land of his birth. He arrived in Buenos Aires on March 9, 1812. Personality and ability caused him to be made commander of the Argentinian forces sent to repel the Spanish-colonial invasion from Upper Peru. Retiring from that command, he went to be Governor of Mendoza, Andean capital of the province of Cuyo, where he began to recruit and discipline the army which was destined to liberate Chile and to inaugurate home rule in Peru. It was a Peruvian congress that gave him the title of "First Soldier of Liberty."'

\footnotetext{
1 Noticias Gráficas, Buenos Aires, December 14, 1949. Quotations from Spanish sources have been translated by the writer.

2 Bartolomé Mitre's Historia de San Martín y de la Emancipación Sudamericana (3 volumes, Buenos Aires, 1887-1888), and José Pacífico Otero's Historia del Liberador Don José de San Martín (4 volumes, Buenos Aires, 1932), are the two most comprehensive biographies of Argentina's famous hero of the independence epoch.
} 
It was only in Peru that the famous Argentinian general, whose all-consuming purpose was to secure independence for the Spanishspeaking colonies in South America, accepted responsibility for the civil government. In Chile Bernardo O'Higgins took over the control of political affairs and left San Martín to devote his whole attention to preparing an expedition against the Spaniards in Peru. Landing a little south of Pisco on September 8, 1820, the liberating army did not enter Lima until July of the following year. On the twenty-eighth of that month its military leaders declared, "Peru is from this moment free and independent by the general will of the people and by the justice of its cause which God defends." Despite the republican sentiment in the old viceregal capital, it appeared that a strong hand would be needed to reconstruct the civil government which had been scuttled when Viceroy José de la Serna marched away to safety in the sierras.

Believing that the interest of the country demanded a vigorous government which would preserve it from the evils of war, license and anarchy, San Martín assumed the title of "Protector" on advice of the leading men of the community, promising the Peruvians that he would most gladly relinquish both civil and military command as soon as the enemy should be driven out. To administer honest justice to all, rewarding virtue and patriotism and punishing vice and sedition wherever they might be found, was to be his norm while exercising supreme authority. ${ }^{3}$ He retained this power from August 3, 1821, to September 20,1822, although the Marqués de Torre Tagle had complete charge over civilian affairs as Supremo Delegado for some seven months of the time.

The Protector's efforts to reform and stabilize social conditions appear to have been in keeping with the spiritual and universal character of the Spanish American revolutions. ${ }^{4}$ They will be considered here under the heading of personal liberty, social restrictions and moral responsibility.

The basic principle of French revolutionary philosophy had been equality, and San Martín turned his attention to personal liberty for

3 J. M. Valega, La Gesta Emancipadora del Perú (10 volumes, Lima, 1941), III, 1-20.

4 The Hispanic American Congress of History, meeting in Madrid in October, 1949, after discussing the problems of independence agreed that the Spanish American revolutions were not isolated episodes, the explanation of which was to be sought in the brusque actuation of one or more concrete causes, but constituted a complete spiritual process, grounded in universal history, for comprehension of which the profound understanding of pre-revolutionary history is essential. El Comercio, Lima, October 30, 1949. 
the Indians, slaves and the individual. First he freed the Indians from all tribute and declared that they should henceforth be known by the name of Peruvians. ${ }^{5}$ On the twenty-eighth of August, 1821, he freed the natives from legal bondage:

Hereby is extinguished the service of Peruvians, be they known by the name of Indians or Natives, and whether they be under the denomination of mitas, pongos, encomiendas, yanaconazgo, and every other class of personal servitude and no one shall be permitted to force them to serve against their will. ${ }^{6}$

The penalty for violators of this law was expatriation.

Before becoming Protector, San Martín had offered freedom to slaves capable of bearing arms, who would join the liberating Army of Peru. From Huaura, a little town north of Lima where he had moved his headquarters from Pisco, he had decreed, on February 7 , 1821, that all slaves in Peru would be free the moment they presented themselves for military service. Payment was guaranteed to masters who were not directly hostile to the American cause, while those who did not present the quota of slaves required of them were to have their property confiscated. In this way troops composed of slaves numbering fifteen hundred were to be recruited. El Depositario, a royalist newspaper in Lima, published the decree on March 24, 1821, to prove that the country would be ruined if the revolutionists won.

The freeing of all children born to slaves after July 28, 1821, was one of the earliest decrees issued by San Martín as Protector. A baptismal certificate would be the only evidence needed to prove freedom. Seven other laws were issued relative to emancipation during the months that followed. Slaves who entered into combat and were distinguished for valor were to remain forever free. Each year on September 7 there was to be a drawing or casting of lots by which twenty-five fortunate slaves would be purchased with funds from the national treasury and set free. Slaves who could prove they were whipped without jurisdiction of the proper local authorities were to be free. A slave would be free if he denounced a master who tried to get his former servants to desert from the army. All slaves belonging to Spaniards or Americans who went to the Iberian Peninsula were free, but they were to present themselves to the army. Slaves who escaped from royalist territory and reached Peru were to receive

\footnotetext{
5 Mariana Santos Quirós, Colección de Leyes, Decretos, y Ordenes (7 volumes, Lima, 1840), I, 21.

B Ibid., 23.
} 
their freedom. ${ }^{7}$ The Supremo Delegado. issued other decrees, and the Peruvian Constitution of 1822 abolished the slave trade.

These laws were not popular with the slaveholders who formed an important element in the opposition which developed against San Martín. The Marqués de Torre Tagle pointed this out and at his suggestion San Martín declared that the slave-owners of Trujillo, whence the Marqués was sending much-needed provisions in great quantities, should receive a hundred and fifty dollars for each slave that was lost. ${ }^{8}$

A bill of rights for the individual was included in the eighth section of the Provisional Statute of Government issued October 8, 1821, in Lima. According to this, every citizen had the equal right to conserve and defend his honor, his liberty, his security, his property and his existence, and no one should be deprived of such rights without due process of law. Anyone who might be defrauded of them would be able to make claims against the government for the infraction and freely publish in the press the cause of his complaint. A special article stated that a man's house was his castle and should be held sacred. In the following section citizenship was granted to all those born in the American states who would swear allegiance to the independence of Peru.

Among the social restrictions imposed by the Protector were those pertaining to corporal punishment, prison reform, smoking in theaters, gambling and mourning. The penalty of azotes or public whipping was abolished. Schoolmasters were not to whip their students; nor were owners of slaves to lash their bonded servants without the intervention of the barrio commissioner or territorial justice under penalty of losing the slave. ${ }^{9}$ On January 3,1822 , the punishment by hanging was made illegal; criminals (desgraciados) condemned to death were to be shot without distinction. However, criminals guilty of treason and sedition after being shot might have their bodies placed on the gallows to make more impressive their punishment. ${ }^{10}$

Prior to that date, humanitarian treatment of prisoners had been

7 Ibid., 16, 24, 30, 52, 65, 74, 83.

8 San Martín to Torre Tagle, March 15, 1821, in Correspondencia Inédita del General José de San Martín con el Marqués de Torre Tagle en los Años de 1820 a 1822 en el Perú. Indice extractado por el Doctor Don José Ortiz de Zevallos Vidaurre y Tagle (Asunción, 1933), No. 22.

9 Quirós, op. cit., I, 52.

10 Gaceta del Gobierno de Lima Independiente, January 5, 1822. This government organ will be referred to hereafter as Gaceta. 
ordered. In October the Protector, accompanied by the ministers of state, various judges and other court officials, had visited all the jails of the capital city with the view of seeing that justice had been done, and of alleviating the miserable conditions of those who had offended society. The civilian and military judges had prepared lists of the prisoners with their alleged offenses and the facts to be considered in each case. The claims and explanations of the delinquents were carefully examined, and this brought about the liberation of some and the less harsh treatment of others. All pending cases were to be settled in twenty days.

The intent of the government was to eliminate the ferocious abuses which the Spanish administration had presumably introduced into criminal legislation. It was decided never again to use the horrible dungeon called infiernilla where men had been buried alive and died of desperation. Every type of torture was to be abolished forever. Jail conditions were to be improved so that those who were suffering for their attacks on society might be converted, by means of useful and moderate work, from immoral and vicious recreants into industrious and useful citizens. ${ }^{11}$

A letter to the editor of El Brujo (Lima, August 30, 1822) from the prisoners of the Cárcel de Guadalupe indicated that all the evils of prison life had not been eliminated. Although there were only a few inmates, they complained that the food was scarce and bad, worse than in times past, and that it seemed to be due to the laziness of those in charge of the jail. Likewise their cases were settled very slowly, which was not in keeping with self-government. As "free men," the prisoners wanted the editor to inform the public so that the people might remedy such conditions.

Smoking, gambling and mourning in extreme forms were subjected to regulation. Performances in theaters had been authorized, but smoking in them was prohibited. ${ }^{12}$ An article in the Gaceta of January 9, 1822, entitled "Public Decorum" noted with great satisfaction the gentility and docility with which this reform, designed only for the interest of the public, had been adopted. Gambling was getting to be a crime which attacked public morality and ruined whole families. The Protector therefore decreed that the owners of gaming-houses were to be imprisoned two months for the first conviction, and six months for a repetition. Those surprised in the act of gambling were

11 Gaceta, October 17, 1821.

12 Quirós, op. cit., I, 92. 
to spend a-month under arrest, and repeaters were to be put in the army as soldiers for the duration of the war. Half of the money found in a gambling-den would go to the State, and the other half to the person reporting the place. All civil and military authorities were charged with seeing that the law was enforced. ${ }^{13}$ Another decree authorized mourning for the prescribed period but the use of black curtains in houses was forbidden. ${ }^{14}$

To inculcate moral and civic responsibility in the individual, San Martín strengthened the position of the Church, founded a patriotic society, established schools and a library, and decreed freedom of the press. "The Roman, Apostolic, Catholic religion," stated article 1 of section 1 of the Provisional Statute of Government, "is the religion of the State; the government recognizes as one of its first obligations to maintain and conserve it by every means which are at the disposition of human prudence. Whoever attacks in public or privately its dogmas and principles shall be punished with the severity in keeping with the offense which he shall have given." Article 2 permitted Christians to dissent on some points from the state religion; they might secure permission from the Council of State to practice their precepts so long as their conduct was not contrary to public order. Although no one was to serve as a public functionary if he did not profess the religion of the State, the liberty of conscience granted by the statute appears to be more liberal than any Peruvian constitution written during the following four decades. ${ }^{15}$

A Patriotic Society of Lima was organized for the purpose of encouraging education and for studying everything that affected the common welfare, be it economic, political or scientific. ${ }^{18}$ Its forty members were appointed from the illustrious intellectual, professional and business men of the community. Under the leadership of the Minister of State, Bernardo Monteagudo, its meetings turned out to be primarily a forum on the type of government best suited to the people of Peru. ${ }^{17}$

13 Gaceta, January 25, 1822.

14 Quirós, op. cit., I, 102.

15 Juan Oviedo, Colección de Leyes, Decretos, y Ordenes Publicadas en el Perí desde el Año de 1821 hasta 31 de Diciembre de 1859 (Lima, 1861), I, 15.

16 Juan Basilio Cortegano in an inedited manuscript entitled Historia del Peru and located in the archives of the National Library in Lima gives an instructive account of this society in chapter 1 of volume 11. It was written in 1858.

17 Monteagudo's Memoria sobre los Principios Politicos que Segui en la Administración del Perú y Acontecimientos Posteriores a mi Separación (Santiago de Chile, 1823), 
In the preamble to the decree establishing the Patriotic Society, San Martín stated that public instruction was the first necessity of any society, and that the government which did not foster it would commit a great crime. The general ignorance, he said, in which the Spanish government had maintained America had been a tremendous act of tyranny. ${ }^{18}$ In the Provisional Statute the presidents of departments were directed to pay particular attention to schools. ${ }^{10}$ One of the last civil duties which the Protector performed before retiring was to attend the inauguration of the Lancastrian method of instruction which Torre Tagle had planned for the College of Santo Tomás. Accompanied by the ministers of state and numerous other dignitaries, he spoke on the neeed of education and the obligations of citizenship. ${ }^{20}$

Great attention was paid to freedom of the press because of its paramount importance to the public. Two early decrees provided that bandas and public notices should be printed exclusively by the government and that all printing was to go free in the mail. ${ }^{21} \mathrm{~A}$ decree of October 13, 1821, clarified the brief section in the Provisional Statute which sanctioned liberty of the press. In it the right of every man to think, speak and write freely was recognized as being essential to the development of the best talent in the nation and the cause of reason.

At the same time some control was seen to be necessary to prevent abuse of the privilege by seditious and perverse people who might use it for purposes of disorganization and vengenance. An individual was to be able to publish his thoughts on any topic without being subjected to any previous censorship, approbation or revision, but punishment was provided for attacks on the dogmas of the Church, moral principles, public tranquillity or the honor of another citizen. A committee to conserve the liberty of the press, consisting of eighteen members, was appointed to see that the law was enforced justly; writers were also safeguarded from prejudices of committee members by the right of appeal. It was made mandatory that the place and date of printing be placed on every publication; and the printer, bookseller or anybody distributing anonymous materials could be held

claims credit for a number of the reforms attributed in this paper to San Martín Written in Quito, the original manuscript of the booklet is now in the library of San Andrés University, La Paz, Bolivia.

18 Gaceta, January $12,1822$.

18 Quirós, op. cit., I, 39.

20 Gaceta, September 16, 1822.

21 Quirós, op. cit., I, 20. 
responsible for their contents. ${ }^{22}$ Much criticism of the government resulted from the freedom granted; accordingly, ten months later the need to protect the public was reiterated in another decree which added that the name of the owner or administrator of the press should also be put on each publication. ${ }^{23}$ Shortly thereafter a law provided that two copies of all printed matter be placed in the National Library.

That edict and the one establishing the National Library appeared in the same issue (August 31, 1822) of the Gaceta del Gobierno. The opening of the library a few weeks later was a brilliant occasion attended by all the elite of the city. San Martín in his address said that the library was destined for universal enlightenment and would be more powerful than armies for the maintenance of independence. ${ }^{24}$ His closing words are carved in marble on a foyer wall of the beautiful library in Lima, completed in 1946:

Every man who desires knowledge can instruct himself without cost in whatever branch or material he may like with the greatest comfort and propriety.

The opening of the National Library must certainly be celebrated as the forerunner of the advancement of sciences and arts in Peru.

Three days after opening the library, Protector San Martín appeared before Congress, which had been elected at his request, and turned over to its members the supreme military and civil authority which he had tried to wield for the peace and happiness of the Peruvian people. ${ }^{25}$ A few years later on receiving a letter from an old friend describing the chaotic conditions in South American republics he replied that he was not surprised: such ills might have been avoided if influential men had been convinced that to defend independence something more than national pride was needed; to defend liberty and its rights

22 Gaceta, October 17, 1821.

23 Gaceta, August 24, 1822.

24. Gaceta, September 18, 1822.

25 The cause of San Martin's retirement is a subject of controversy among South American historians. His own explanation, written in a letter to William Miller, April 19, 1827, from self-imposed exile in Brussels, was that he withdrew in order to make possible the coming of General Simón Bolivar with sufficient reinforcements from Colombia to guarantee victory over the strong Spanish army in Peru. This viewpoint is the theme of a book by Capitán de Fragata Jacinto R. Yaben, Por los Fueros de Gral. San Martín (Buenos Aires, 1950). It is contradicted by Vicente Lecuna in La Entrevista de Guayaquil, Publicaciones de la Academia de la Historia de Venezuela (Caracas, 1948), which incidentally was printed in Buenos Aires. 
citizens were needed, not of wealth but of enlightenment and elevation of soul..$^{28}$

In view of the work of the illustrious statesman-General whom the Republic of Argentina proposed to honor throughout the year 1950, one biographer has written the following characterization: "San Martín belongs to all independent America because of his social action, and to all mankind because of the moral mastery which universalizes him."2z

WiLliam H. Gray

The Pennsylvania State College

${ }^{26}$ San Martín to Tomás Guido, January 6, 1827, Documentos del Arcbivo de San Martín (12 vols., Buenos Aires, 1910), VI, 512.

${ }^{27}$ Ricardo Rojas, El Santo de la Espada (Buenos Aires, 1940), 10. 